\title{
人間型ロボットの作業移動 一作業移動に要求される脚機能の分析一
}

\author{
吉 田 晴 行* 井上健 司* 新 井 健 生* 前 泰 志* \\ Mobile Manipulation of Humanoid Robots \\ - Analysis of the Required Function of Legs in Mobile Manipulation-
}

\author{
Haruyuki Yoshida*, Kenji Inoue*, Tatsuo Arai* and Yasushi Mae*
}

\begin{abstract}
This paper describes mobile manipulation of humanoid robots. A humanoid robot is a kind of integrated machines: a two-arm and two-leg mechanism. It could be well applied to mobile manipulation in non-routine task automation. The main objective of the mobile manipulation is to obtain versatile and efficient manipulation by the arms. In this respect the legs are required to assist the arms obtaining their high manipulability by changing step length and timing of step motion. The required motion of the legs in mobile manipulation is different from the conventional biped locomotion. From this point of view, we discuss and analyze the required motion of legs in mobile manipulation. We propose a basic idea to quantitatively evaluate robot performance in mobile manipulation. Because manipulability and stability vary during the robot motion, we take an average and a variance of manipulability measure of arm, and an average and a minimum of stability margin per a locomotion cycle as an evaluation criterion. By computer simulations, the relationship between these evaluations and some patterns of leg motion is analyzed by using the proposed control method of mobile manipulation. The simulation results show that the leg motion can vary the manipulability of the arm by changing the step length and the timing of the step motion. It is also found that the manipulability of the arm and the stability of the robot are closely related.
\end{abstract}

Key Words: Mobile Manipulation, Integrated Motion Centered Manipulation, Manipulability, Humanoid Robot, Redundant Mechanism, Motion Analysis

\section{1. 序}

論

アーム機能と移動機能を併せ持つ作業移動型ロボットは一般 に, ロボットアーム単体と比較して作業能力を増強できる特徽 を持つ。例えば，移動の自由度によりアームの動作領域を拡大 できる点や，機構の圥長自由度を利用した器用なマニピュレー ションが可能となる点である.これらの特徵に着眼し，ハード ウエア開発や制御手法の提案など, 多数の研究がこれまでに報 告されている [1] [2].アームを移動プラットフォームに搭載した もの [3]〜 [5]や，生物の形態を参考とした昆虫型 $[6] \sim[8] \cdot$ 人間 型 [9] [10] 等がその例であり, 様々な作業環境下での応用が期待 できる，筆者らは，作業移動型ロボットの研究で目指すべき課 題の一つとして, 作業対象のマニピュレーションやハンドリン グの中心はロボットアームであることに注目し，移動機能によ クアーム機能を補完・増強させる手法の提案に重点を置く。ま た移動プラットフォームとしては，不整地や段差が伴う作業環

原稿受付 2000 年 6 月 16 日

*大阪大学大学院基礎工学研究科

${ }^{*}$ Graduate School Of Engineering Science, Osaka University
境下でも適用可能な脚式を対象とする.

筆者らの制御指針とする作業移動とは，先に述べたように，作 業移動型ロボットが持つ移動機能により，アーム機能を補完・ 増強させる統合動作を意味するアアームによる器用かつ効率的 なマニピュレーションを実現することが，作業移動の主な目的 である．よって，アームを操作性の高い状態に維持するための 運動が, 移動プラットフォームに求められる. 脚式作業移動型 ロボットでは, その具体的な方法として，1）脚接地点の変更, 2）脚の屈伸動作，による移動プラットフォームの位置姿勢の調 整が挙げられる，ただし，その本体が土台に固定されていない ので, 安定性を維持できる範囲で, アーム機能を発揮できる脚 の動作制御を検討する必要がある.

脚式作業移動型ロボットのうち人間型に関しては，すでに高 度なハードゥエアが開発された [9]〜 [11]. しかし，歩行中心の 動作制御に重点を置いた研究が盛んであり [12] [14], 筆者らが 意図するアームを中心とした動作制御に関する報告は，これま でにない.

このような観点から，筆者らは人間型ロボットに作業移動を 実現させる制御手法の開発に取り組んでいる。これまでに提案 
した手法 [15] [16] の主な特徴は以下の 3 点に集約される. (1) アーム先端に未知外力が作用する状況下でインピーダンス制御 により,アーム先端はつねに目標軌道に追従する, (2) 肩はアー ムの操作性とロボットの安定性が改善される方向に制御される, （3）脚の接地点を变更することにより操作性と安定性が改善さ れる場合，脚はあらかじめ決められた棈円軌道に沿って踏み換 える，ただしこの手法では，脚動作パラメータである歩幅と踏 み換えタイミングを固定している．しかし，精度や外乱の有無 といったアームに要求される作業条件に応じて脚動作パラメー 夕を調整することは，アームの作業能力を増加させる有効な手 段と考えられる．例えば，歩幅の小さい動作では，立ち位置の 微調整が可能になるので, アームを操作性の高い状態に維持し たマニピユレーションを実現できる。一方，歩幅の大きな動作 では, 安定領域の絶対幅が大きいことから, 外乱が作用しても 安定なマニピュレーションを維持できる。

そこで本論文では，作業移動型ロボットを対象とした作業移 動の概念を提案し, 人間型ロボットに作業移動を適用する場合 の, 脚の動作制御における着眼点および技術課題ついて論じる. そして, 脚動作パラメータとアームの操作性・ロボットの安定 性の間にみられる相関関係を明らかにし，パラメー夕調整によ りアームの作業能力を拡大する手段について考察する，具体的 には，歩幅・踏み換えタイミングの組み合わせが異なる脚動作 についてアームの可操作度 [17] とロボットの安定余裕を評価指 標とし，パラメータ設定值が評価指標に与える影響を比較する。 以下, 2 章では作業移動の概念について述べ, 人間型ロボット に作業移動を実現させる際に検討すべき脚の動作制御手法につ いて論ずる. 3 章では動作比較に用いる制御手法 [16] の概要を 述べる. 4 章ではコンピュータ・シミュレーションにより, 脚 動作パラメータが異なる場合の評価指標の変化について考察し, パラメー夕調整によりアームの作業能力を拡大する制御手法の 設計指針を明らかにする。

\section{2. 作 業 移 動}

\section{1 作業移動の概念}

本研究の制御指針とする「作業移動」とは，作業移動型ロボッ トが持つ移動機能により，アーム機能を補完・増強させる統合 動作を意味する。アームによる器用かつ効率的なマニピュレー ションを実現することが，作業移動の主な目的である。よって， アームを操作性の高い状態に維持するための運動が, 移動プラッ トフォームに求められる。これは,アームの自由度を除くシス テムの圥長自由度を利用し，アームのベース部として適切な位 置調節を行うことである。ただし，土台が固定された産業用口 ボットアームと異なり, 安定性も確保することが望まれる。脚 式作業移動型ロボットでは, その具体的な方法として，1）脚接 地点の変更, 2) 脚の屈伸動作, による移動プラットフォームの 位置姿勢の調整が挙げられる，以下では人間型ロボットに作業 移動を適用する場合の，脚の動作制御における着眼点拉よび技 術課題を述べる.

\section{2 作業移動に要求される脚動作}

従来の産業用ロボットアームは, 土台が固定されているため その作業領域が極めて限定された。一方, 人間型ロボットはアー

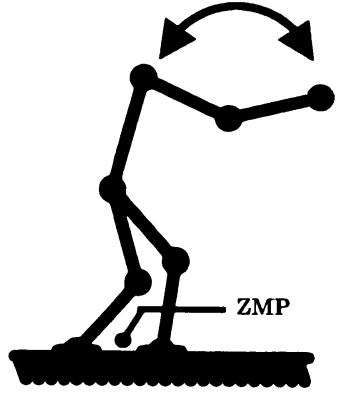

(a) low manipulability, high stability

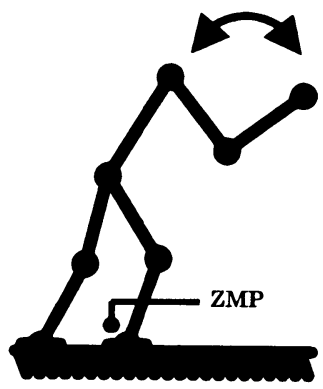

(b) high manipulability, low stability
Fig. 1 By utilizing the redundancy of mechanism, leg motion can augment arm's manipulability by (a) $\rightarrow$ (b), while decreasing stability

ム機能と移動機能が統合された作業移動型ロボットであるため, 移動機能が持つ運動の自由度によりアームの動作領域を拡大で きる.この特徴に加えて, アームと移動機構から構成されるて 長自由度系となるので, 特定の作業点にアーム先端を位置決め した状態で, 脚・胴体の姿勢調整や脚接地点の変更によりアー ムの操作性を改善できる。ただし Fig. 1 に示すように，ロボッ 卜本体が土台に固定されていないので, 安定性を維持できる範 囲で，アーム機能を発揮できる脚の動作制御を検討する必要が ある。

-Point-A：安定領域制限内で機構が持つ尣長性を利用し,アー ムの作業能力を増加させる.

次に, 脚式の特徵は脚接地点を選択できる点にある。よって, アーム先端の運動方向・運動速度に応じて脚動作パラメータ歩幅・踏み換え夕イミング一を調節することで, アームの操作 性やロボット本体の安定性は改善できると考えられる。例えば, 歩幅が小さく単脚支持期が短い動作では, 立ち位置の微調整が 可能になるので, 広範囲におけるアーム先端の運動に対しアー ムの操作性を高く維持したマニピュレーションを実現できる。た だし, 狭い安定領域しか確保できないため, 未知外乱や外力を 伴う作業に不向きとなる，歩幅が大きな動作では，安定領域の 絶対幅が大きいことから，未知外乱や外力が作用しても安定な マニピュレーションを維持できる. ただし, 立ち位置の微調整 が困難となることから, 精度の要求される作業に対し不向きと なる。これらの性質に注目すると，アームの操作性やロボット 本体の安定性を, 共に高い状態へ改善していくパラメータの組 み合わせが必ずしも存在しない（Fig. 2). したがって，精度や 外乱等の作業条件に応じてアームの作業能力を増加させるため のパラメータ調整が必要となる。

- Point-B：作業条件に応じて脚動作パラメー夕を調整する ことにより，アームの作業能力を増加させる。

人間型ロボットに作業移動を実現させる場合，上記の 2 点を もとに制御手法を検討する必要がある。筆者らはすでに, PointAの観点より制御手法の一提案を行った [15] [16]. 本論文では Point-Bの観点から， パラメー夕調整によりアームの作業能力 を拡大させる制御手法の設計指針を明らかにする。 


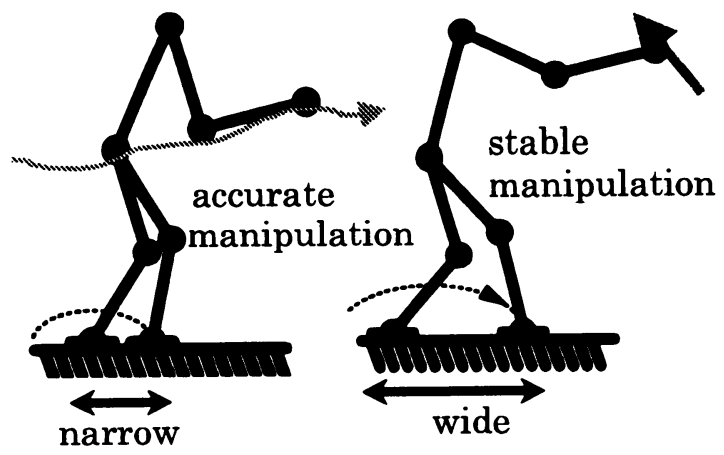

Fig. 2 By adjusting leg motion parameters in accordance with manipulation, manipulability and stability are improved. However, set of parameters for improving all of these performances does not necessarily exit

\section{3. 制御手法の概要}

本章では, 脚動作の分析に使用する制御手法の概要を述べる. 詳細については文献 [16] を参照する。

\section{1 モデル}

本研究では, sagittal plane 上でのロボットの運動を考える. そしてアーム先端には未知な外力が作用しているものとする (Fig. 3). リンクモデルは一つのアームと脚部で構成されてい るものとし, 胴体リンクと二脚を併せて脚部と呼ぶ. 以下, “位 置・姿勢”を “位置”, “力・モーメント”を“力”と表記する. $\boldsymbol{r}_{e} \in \Re^{3}, \boldsymbol{r}_{s} \in \Re^{3}, \boldsymbol{r}_{w} \in \Re^{3}$ はそれぞれ, アーム先端の位置, 肩そして遊脚先端の位置ベクトルを示す. 図より $\boldsymbol{r}_{e}, \boldsymbol{r}_{s}$ そし て $\boldsymbol{r}_{w}$ が決定すると, ロボットの全関節変数 $\boldsymbol{q}$ は逆運動学より 一意に求まる，以下では，制御の流れを説明する。

\section{2 アーム先端のインピーダンス制御}

アームのマニピュレーションに関する望みの挙動として, 式 （1）に示すインピーダンス特性がアーム先端に対し与えられて いるものとする.

$$
M_{e} \ddot{\boldsymbol{r}}_{e}+D_{e} \dot{\boldsymbol{r}}_{e}+K_{e}\left(\boldsymbol{r}_{e}-\boldsymbol{r}_{e d}\right)=\boldsymbol{f}-\boldsymbol{f}_{d}
$$

ただし $\boldsymbol{f} \in \Re^{3}, \boldsymbol{f}_{d} \in \Re^{3}, \boldsymbol{r}_{e d} \in \Re^{3}$ はそれぞれ, アーム先端 への外力. 目標力, 目標位置ベクトルを示す. $M_{e}>0 \in \Re^{3 \times 3}$, $D_{e}>0 \in \Re^{3 \times 3}, K_{e}>0 \in \Re^{3 \times 3}$ はそれぞれ, アーム先端の 挙動における望みの慣性行列, 粘性係数行列, 剛性行列である.

\section{3 評価関数}

脚部は, 次に示す評価関数 $\boldsymbol{U}$ を最小にするように制御される.

$$
\boldsymbol{U}\left(\boldsymbol{r}_{e}, \boldsymbol{r}_{s}, \boldsymbol{r}_{w}, \boldsymbol{f}\right) \equiv \boldsymbol{U}_{z}+\boldsymbol{U}_{a}+\boldsymbol{U}_{b} \rightarrow \min
$$

ここで $\boldsymbol{U}_{a}, \boldsymbol{U}_{b}$ および $\boldsymbol{U}_{z}$ はそれぞれ, アームの操作性, 脚 部の特異姿勢回避, ロボットの転倒安定性に用いる評価関数を 示す.

各評価関数は以下に示す式で表現される.

$$
\boldsymbol{U}_{z}\left(\boldsymbol{r}_{e}, \boldsymbol{r}_{s}, \boldsymbol{r}_{w}, \boldsymbol{f}\right) \equiv K_{z}\left(x_{z}-x_{z d}\right)^{2}
$$

ただし, 係数 $K_{z}>0 . x_{z}$ は, 各リンクの重力によるモーメン

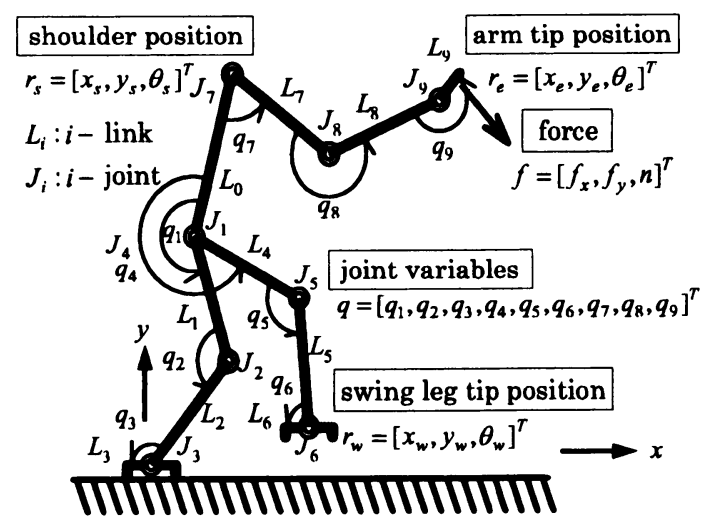

Fig. 3 Link model of the robot and its variables

トと,アーム先端に作用する外力 $\boldsymbol{f}$ によるモーメントの総和が ゼロとなる床面上の点を意味する，マニピュレーションを主体 とする統合動作を実現する上で, 加減速の著しい運動が脚に要 求されないものと想定し, 現段階では慣性力によるモーメント を含めていない． $x_{z d}$ は安定領域内に設定された目標 ZMP で あり，その設定方法は次節以降で説明する。

$$
\boldsymbol{U}_{a}\left(\boldsymbol{r}_{e}, \boldsymbol{r}_{s}\right) \equiv\left\{\left(\boldsymbol{r}_{s}-\boldsymbol{r}_{e}\right)-\overline{\boldsymbol{r}}_{s e}\right\}^{T} \frac{K_{a}}{2}\left\{\left(\boldsymbol{r}_{s}-\boldsymbol{r}_{e}\right)-\overline{\boldsymbol{r}}_{s e}\right\}
$$

ただし，係数行列 $K_{a}>0 \in \Re^{3 \times 3} . \overline{\boldsymbol{r}}_{s e} \in \Re^{3}$ は $\left(\boldsymbol{r}_{s}-\boldsymbol{r}_{e}\right)$ の 理想値を示し, アームの可操作度 [17] が最大値をとるように設 定する。ここでアームの可操作度とは，アームのみの姿勢によ り規定される可操作度を意味し, 脚部の自由度による可操作度 は含めていない.

$$
\boldsymbol{U}_{b}\left(\boldsymbol{r}_{s}\right) \equiv\left\{\boldsymbol{r}_{s}-\overline{\boldsymbol{r}}_{s}\right\}^{T} \frac{K_{b}}{2}\left\{\boldsymbol{r}_{s}-\overline{\boldsymbol{r}}_{s}\right\}
$$

ここで, 係数行列 $K_{b}>0 \in \Re^{3 \times 3} . \overline{\boldsymbol{r}}_{s} \in \Re^{3}$ は脚部の特異姿 勢回避のための理想位置べクトルを示す.

\section{4 両脚支持における脚部の制御手法}

両脚支持状態では, 遊脚先端の位置 $\boldsymbol{r}_{w}$ は一定であり歩幅に 相当する. そして, アーム先端の位置 $\boldsymbol{r}_{e}$ と外力 $\boldsymbol{f}$ は式 (1) よ り既知となる。ここで, 評価関数 $U$ が最小になるように, 式 （6）を用いて肩の位置 $\boldsymbol{r}_{s}$ を制御する.

$$
M_{s} \ddot{\boldsymbol{r}}_{s}+D_{s} \dot{\boldsymbol{r}}_{s}=-\partial U / \partial \boldsymbol{r}_{s}
$$

ただし $M_{s}>0 \in \Re^{3 \times 3}$ と $D_{s}>0 \in \Re^{3 \times 3}$ はそれぞれ, 肩の 挙動における望みの慣性行列, 粘性係数行列である. なお両脚 支持状態 (left in Fig. 4) では, ZMP の目標值 $x_{z d}$ を安定領 域中央に設定する.

\section{5 単脚支持における脚部の制御手法}

式 (1) より拘束されるアーム先端の位置 $\boldsymbol{r}_{e}$ に対し, 評価関 数 $\boldsymbol{U}$ を用いて踏み換えの判断を行う. まず，A）現在の両脚支 持状態，と B）アーム先端の運動方向に歩幅一歩分踏み換えた 両脚支持状態，についてそれぞれ，肩が最適位置となる $U$ を $\boldsymbol{U}_{m 1}, \boldsymbol{U}_{m 2}$ とする. 条件 $\boldsymbol{U}_{m 1}<\boldsymbol{U}_{m 2}$ が成立した場合，A） の, 現在の両脚支持状態のままで式（6）により肩が制御され る. 条件 $\boldsymbol{U}_{m 1}>\boldsymbol{U}_{m 2}$ が成立した場合, B ）の両脚支持状態へ 
Table 1 Outline of $x_{z d}$ control during step motion of legs

\begin{tabular}{|c||l|}
\hline state & \multicolumn{1}{|c|}{$x_{z d}$ control } \\
\hline \hline double support & $\begin{array}{l}x_{z d} \text { is placed on } \\
\text { the center of stable region }\end{array}$ \\
\hline $\begin{array}{c}\text { transition from double } \\
\text { to single support }\end{array}$ & $\begin{array}{l}x_{z d} \text { is moved to } \\
\text { the center of sole of support leg }\end{array}$ \\
\hline single support & $\begin{array}{l}x_{z d} \text { is placed on } \\
\text { the center of sole of support leg }\end{array}$ \\
\hline $\begin{array}{c}\text { transition from single } \\
\text { to double support }\end{array}$ & $\begin{array}{l}x_{z d} \text { is moved to } \\
\text { the center of stable region }\end{array}$ \\
\hline
\end{tabular}

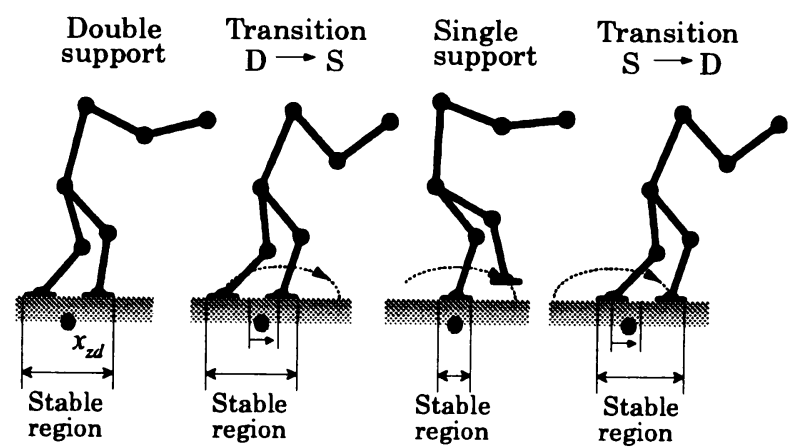

Fig. 4 Image of $x_{z d}$ control during step motion of legs

と立ち位置を移行させる。その際, (i) ZMP の目標値 $x_{z d}$ は, Table 1 に従い移行する (Fig. 4 も参照する), (ii) 肩の位置 $\boldsymbol{r}_{s}$ は式 (6) によって制御される, (iii) 脚はあらかじめ決められ た楕円軌道に沿って踏み換える。ここで，棈円軌道は歩幅 $w_{s}$ ， 単脚支持時間 $t_{s}$ と両脚支持移行時間 $t_{t}$ の関数である.

\section{4. 作業移動における脚動作の評価と考察}

本章では，パラメー夕設定值の組み合わせが異なる脚動作を 比較し，その設定值によってアームの操作性やロボットの安定 性がどのように変化するかを定量的に評価する，特に本論文で は，踏み換え動作を必要とする広範囲にわたるマニピュレーショ ンを想定し，その簡素化した入力として，アーム先端に等速運 動を与える。ただし，実際の非定型作業では，この基本動作を 中心に未知外乱や外力がアーム先端に作用するものと思われる. そこで, アームの可操作度 [17] とロボットの安定余裕を評価指 標として用いる。アームの可操作度を評価することは，上述し た状況下でのマニピュレーションに対し，アームが対処しうる かを判断する尺度となる。

動作比較に用いるモデルの物理パラメータを Table 2 に示す. また制御則内で固定するパラメータを Table 3 に示す.アー 么先端に与える速度 $v_{e}\left(=\dot{\boldsymbol{r}}_{e d}\right)$ は $0.05[\mathrm{~m} / \mathrm{s}]$ の一定值とし, 以 下に示す二つのパラメー夕設定值をかえて実験する。すなわち， 歩幅 $w_{s}$ と, 踏み換え時間 $t_{c y}\left(=w_{s} / v_{e}\right)$ において両脚支持移 行状態 (transition state in Fig. 4) が占める時間割合 $C_{t}$ であ る. 単脚支持状態 (single support state in Fig. 4) が占める割 合 $C_{s}$ は, 踏み換え時間全体に $C_{t}$ が占める割合の残りを割り 当てる.これにより，両脚支持移行時間 $t_{t}$ と単脚支持時間 $t_{s}$
Table 2 Parameters of robot model used in simulation

\begin{tabular}{|c||c|c|}
\hline Link number & Length [m] & Weight [Kg] \\
\hline \hline$L_{0}$ & 0.624 & 34.8 \\
\hline$L_{1}, L_{4}$ & 0.542 & 11.5 \\
\hline$L_{2}, L_{5}$ & 0.434 & 17.0 \\
\hline$L_{3}, L_{6}$ & 0.480 & 0.00 \\
\hline$L_{7}$ & 0.542 & 19.0 \\
\hline$L_{8}$ & 0.597 & 0.00 \\
\hline
\end{tabular}

Table 3 Parameters of control method in simulation

\begin{tabular}{|l||l|c|}
\hline \multicolumn{3}{|c|}{ Arm control } \\
\hline \hline Mass & $M_{e}[\mathrm{Kg}]$ & 0.900 \\
\hline Damping & $D_{e}[\mathrm{Nsec} / \mathrm{m}]$ & 8.00 \\
\hline Stiffness & $K_{e}[\mathrm{~N} / \mathrm{m}]$ & 21.0 \\
\hline \hline \multicolumn{3}{|c|}{ Leg control } \\
\hline \hline Mass & $M_{s}[\mathrm{Kg}]$ & 3.00 \\
\hline Damping & $D_{s}[\mathrm{Nsec} / \mathrm{m}]$ & 57.0 \\
\hline Stiffness & $K_{a}[\mathrm{~N} / \mathrm{m}]$ & $4.98 \times 10^{1}$ \\
& $K_{z}[\mathrm{~N} / \mathrm{m}]$ & $2.23 \times 10^{3}$ \\
& $K_{b}[\mathrm{~N} / \mathrm{m}]$ & $1.70 \times 10^{2}$ \\
\hline Desired distance between & $\bar{x}_{e}[\mathrm{~m}]$ & 0.804 \\
arm tip and shoulder & & \\
\hline Desired height of shoulder & $\bar{y}_{s}[\mathrm{~m}]$ & 1.36 \\
\hline
\end{tabular}

(Desired impedance: $\mathbf{x}$ and $\mathbf{y}$ direction)

が, $t_{c y} \cdot C_{t}$ と $t_{c y} \cdot C_{s}$ から求まり, 踏み換え時の遊脚の運動が 決定する。本論文では, 歩幅 $w_{s}=0.2,0.3,0.4,0.5[\mathrm{~m}]$ と両脚 期移行時間割合 $C_{t}=30,50,70 \%$, 計 12 の組み合わせから なる脚動作を比較する. 制御のサンプリング周期は $4.0[\mathrm{~ms}]$ で ある。

脚動作パラメー夕の設定值が異なる動作例を Fig. 5, 6 に示す. 設定值の組はそれぞれ， $w_{s}=0.3[\mathrm{~m}], C_{t}=70 \%, C_{s}=30 \%$ と $w_{s}=0.3[\mathrm{~m}], C_{t}=30 \%, C_{s}=70 \%$ であ. Fig. 5,6 の (b), (c) より, アームの可操作度とロボットの安定余裕は, 踏み換え 動作中のロボットの姿勢変化に伴い変動している。よって, 踏 み換え動作が終了するまでの時間幅における指標の平均值・分 散値や最小值に注目し, 評価指標の時間変動を含めた評価を行 う必要があることが分かる。

計 12 のパラメータの組み合わせについて, アームの操作性と ロボットの安定性の評価結果を Fig. 7，8 に示す. Fig.7 (a) (c) において, 水平軸は両脚期移行時間割合 $C_{t}$ を示し, 鉛直 軸は正規化されたアームの可操作度を示す.Fig. 8 (a), (b) に おいて, 水平軸は両脚期移行時間割合 $C_{t}$ を示し, 鉛直軸は口 ボットの安定余裕を示す．以下，アームの操作性を評価する場 合は, Fig. 7 (a)〜 (c) を参照し，ロボットの安定性を評価する 場合は, Fig. 8(a), (b) を参照する.

\section{1 脚移動時間割合に関する評価}

両脚期移行時間割合 $C_{t}$ が異なる 2 種類の脚動作を比較する. ここで $C_{t}=30,70 \%$, 歩幅は $w_{s}=0.3[\mathrm{~m}]$ の一定值である. 結果より，以下に示す関係が明らかになった。

・アームの操作性の評価：

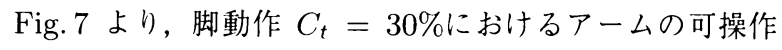
度分散值は， $C_{t}=70 \%$ の際に比べて大きな值を示した。 Fig. 5 (a) より単脚支持期では, 一定速度でアーム先端が進 


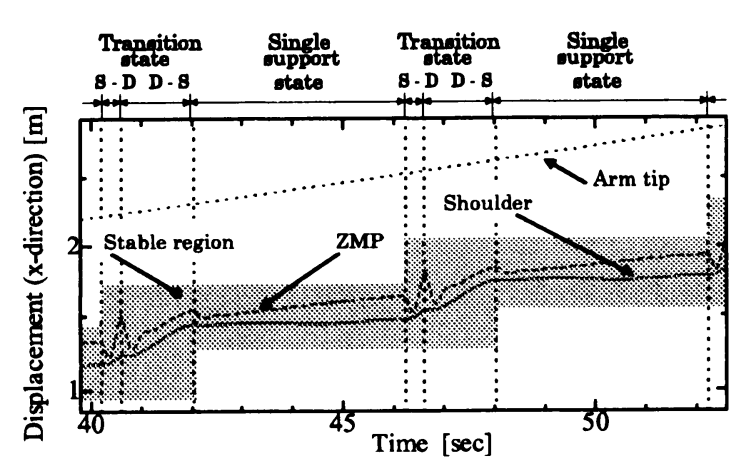

(a) Arm tip and shoulder motion in $x$ direction

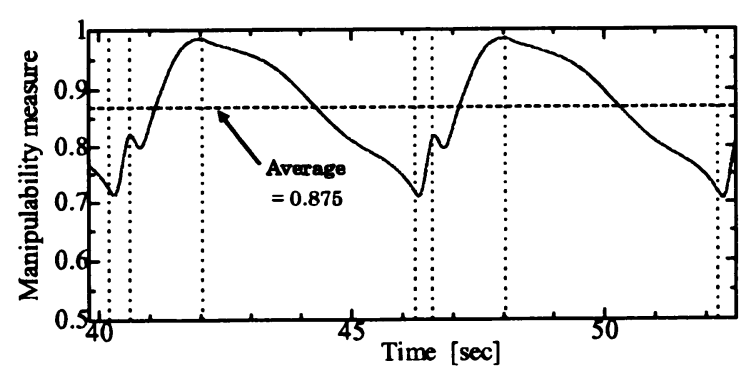

(b) Normalized manipulability measure

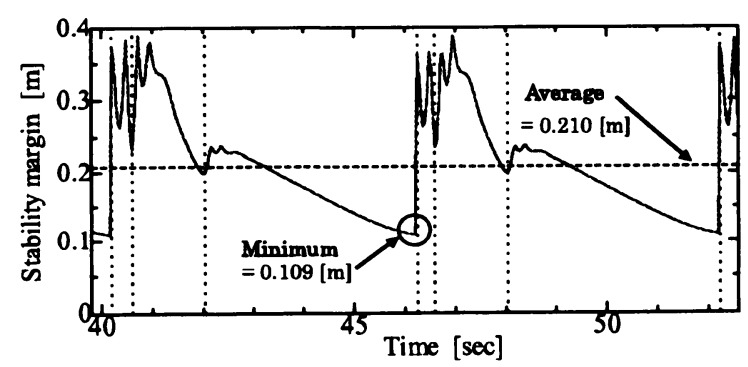

(c) Stability margin

Fig. 5 An example of simulation results when: $w_{s}=0.3[\mathrm{~m}]$, $C_{t}=30 \%, C_{s}=70 \%$

行方向に変位するのに対し, 狭い安定領域内に ZMP を維 持するために肩が制御される。結果として, 進行方向にお けるアーム先端と肩の相対距離を一定に保った状態で, 肩 はアーム先端に追従することができない. 一方, Fig. 7 よ

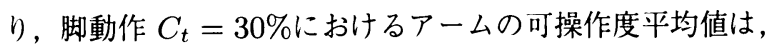
$C_{t}=70 \%$ の際に比べて高い値を示した.

・ロボットの安定性の評価：

Fig. 8 (a) より, 脚動作 $C_{t}=30 \%$ における安定余裕の平均 值は， $C_{t}=70 \%$ 際に比べて小さい值を示した。これは Fig. $5(\mathrm{a})$ より， $C_{t}=30 \%$ で脚動作は単脚支持期が長い ので, 安定領域の絶対幅が制限され続けるためである. 一 方, Fig. 8 (b) より, 脚動作 $C_{t}=30 \%$ におる安定余裕の 最小值は $C_{t}=70 \%$ の際に比べて高い值を示した。これは $C_{t}=70 \%$ での脚動作の方が, 慣性力が大きく作用するた めである。

\section{2 歩幅に関する評価}

歩幅 $w_{s}$ が異なる 2 種類の脚動作を比較する.ここで $w_{s}=$

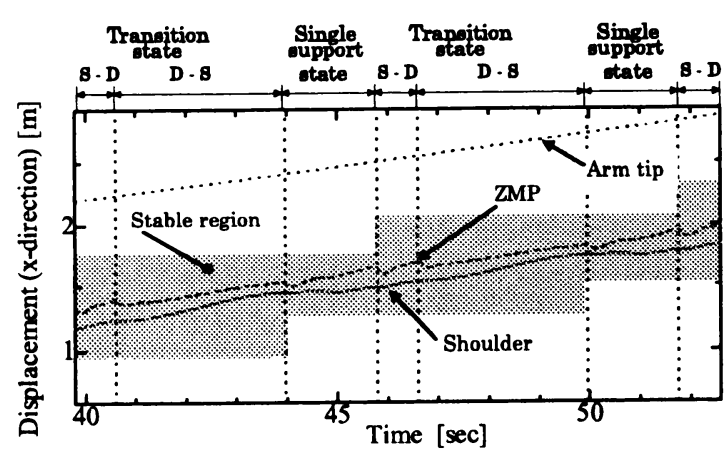

(a) Arm tip and shoulder motion in $x$ direction

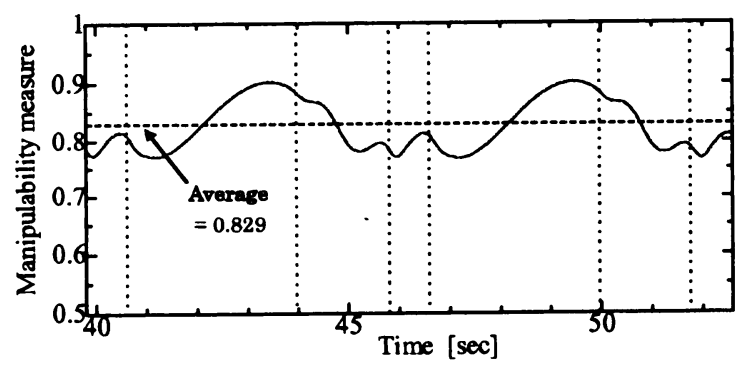

(b) Normalized manipulability measure

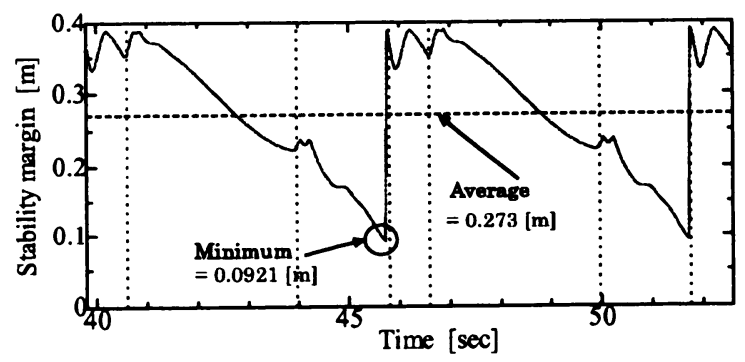

(c) Stability margin

Fig. 6 An example of simulation results when: $w_{s}=0.3[\mathrm{~m}]$, $C_{t}=70 \%, C_{s}=30 \%$

$0.2,0.5[\mathrm{~m}]$, 両脚期移行時間割合は $C_{t}=70 \%$ 一定值である. 結果より，以下に示す関係が明らかになった。

-アームの操作性の評価 :

Fig. 7 (b) と Fig. 7 (c) より, 脚動作 $w_{s}=0.2[\mathrm{~m}]$ におけ るアームの可操作度分散值は, $w_{s}=0.5[\mathrm{~m}]$ の際に比べて 小さい值を示した.これは $w_{s}=0.2[\mathrm{~m}]$ の脚動作が頻繁に 脚を踏み換えて移動するので，アーム先端と肩の位置誤差 を減少させることができるためである.一方, Fig.7 (a) よ $\eta$, 脚動作 $w_{s}=0.2[\mathrm{~m}]$ におけるアームの可操作度平均值 は, $w_{s}=0.5[\mathrm{~m}]$ の際に比べて高い值を示した.

・ロボットの安定性の評価：

Fig. $8(\mathrm{a})$ より, 脚動作 $w_{s}=0.2[\mathrm{~m}]$ における安定余裕 の平均値は, $w_{s}=0.5[\mathrm{~m}]$ の際に比べて小さい值を示し た.これは, 脚動作 $w_{s}=0.2[\mathrm{~m}]$ における安定領域の絶 対幅が, $w_{s}=0.5[\mathrm{~m}]$ の際に比べて狭いためである. 一 方, Fig. 8 (b) より, 脚動作 $w_{s}=0.2[\mathrm{~m}]$ における安定余 裕の最小值は, $w_{s}=0.5[\mathrm{~m}]$ の際に比べて高い值をとる. 


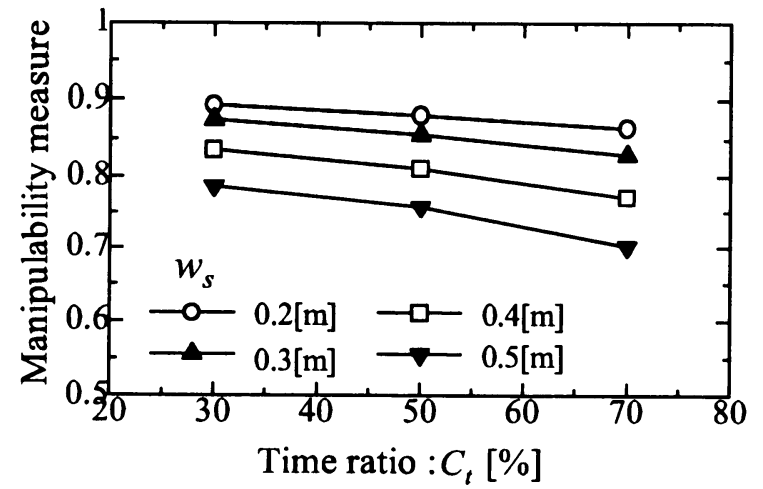

(a) Normalized manipulability measure (average/step motion)

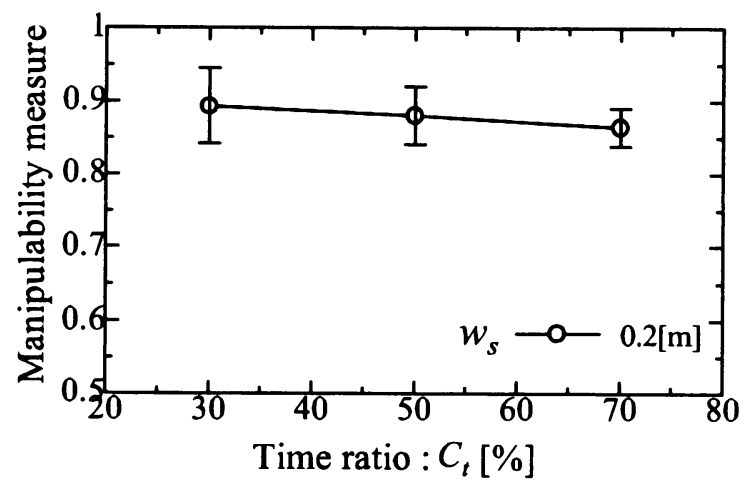

(b) Normalized manipulability measure (variance/step motion)

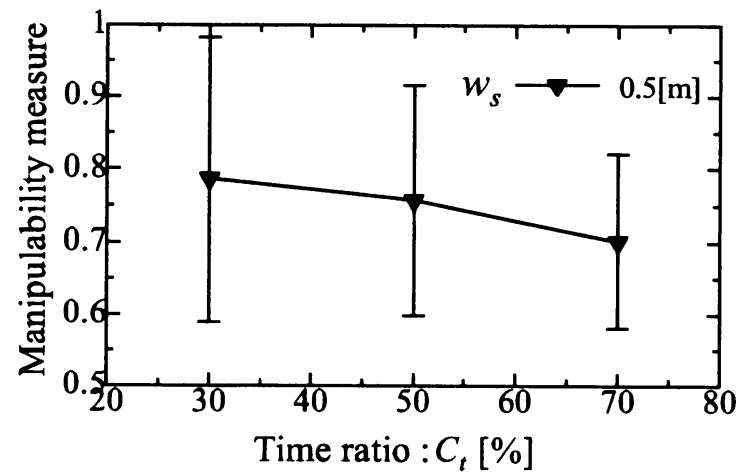

(c) Normalized manipulability measure (variance/step motion)

Fig. 7 Estimation of Manipulability

脚動作 $w_{s}=0.2[\mathrm{~m}]$ では，ロボット全体の姿勢変化が, $w_{s}=0.5[\mathrm{~m}]$ の際に比べて小さいため, 脚接地時に生ずる 慣性力が小さくなるためである.

\section{3 脚動作パラメータが操作性と安定性に与える影策}

脚動作パラメータとアームの操作性・ロボットの安定性につ いて, 得られた知見は以下の通りである.

- 歩幅の小さい踏み換え動作は, アームの可操作度平均値を 高く維持すると共に分散值も抑制できる（Fig. 7 (a),(b)). その反面, 安定余裕の平均值は低い值を示す。一方, 歩幅 の大きな動作では, 可操作度の平均值を低下させるが, 安 定余裕の平均值を高く維持できる（Fig. 8 (a)).

-両脚支持移行期が長い踏み換え動作は, 高い安定余裕平均

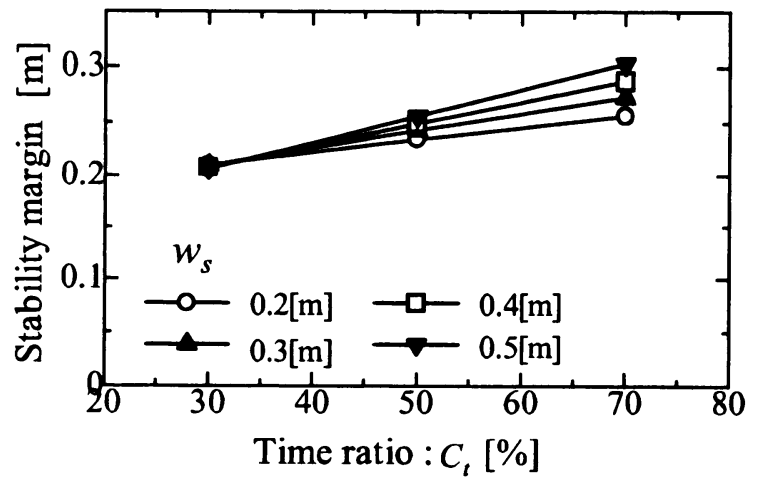

(a) Stability margin (average/step motion)

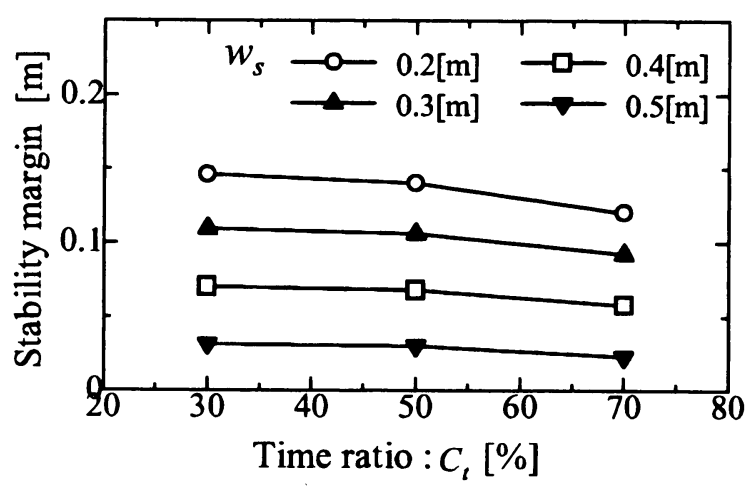

(b) Stability margin (minimum/step motion)

Fig. 8 Estimation of Stability

值を維持できる（Fig. 8 (a))．また可操作度の分散值を抑 制できる (Fig. 7 (a)). その反面，安定余裕の最小值は低下 する傾向がみられる (Fig. 8 (b)).

以上より, 操作性や安定性についての各評価指標を, 共に改 善するパラメータの組が必ずしも存在しないことが分かる。こ の性質に注目すると, 精度や外乱といった作業条件に応じて, 脚 動作パラメータを調整することが，アームの作業能力を増加さ せるために必要であることも分かる，なお，Table 3 に挙げた パラメー夕設定值をかえた場合にも，同様の傾向が確認された。

\section{5. 結論}

本論文では，作業移動型ロボットを対象とし，移動機能によ りアーム機能を補完・増強させる統合動作「作業移動」の概念 を提案した。また，人間型ロボットに作業移動を適用する場合 の, 脚の動作制御における着眼点および技術課題について論じ た，歩行を目的とした脚の動作制御では，歩幅・踏み換えタイミ ングの調整を特に必要としない。しかし，アームの作業能力を 増加させる脚の動作制御では，これらの調整が重要となる。そ こで, パラメータ設定値の組み合わせが異なる脚動作を比較し, その設定值によってアームの操作性やロボットの安定性がどの ように変化するかを定量的に評価した。得られた知見は以下の 通りである。

（1）評価指標に用いたアームの可操作度とロボットの安定余裕 は，踏み換え動作中のロボットの姿勢变化に伴い変動する. 
そこで, 踏み換え動作が終了するまでの時間幅における指 標の平均値・分散値や最小值に注目し, 評価指標の時間变 動を含めた評価を行う必要がある。

（2）歩幅の小さい踏み換え動作は，アームの可操作度平均值を 高く維持すると共に分散值も抑制できるので, 精度が要求 される作業に対し有効である。 その反面, 安定余裕の平均 值は低い值を示す。一方, 歩幅の大きな動作では, 安定余 裕の平均值を高く維持できるので, 未知外乱や外力が作用 する作業において安定なマニピュレーションが可能となる。

（3）両脚支持移行期が長い踏み換え動作は, 高い安定余裕平均 值を維持できる。また可操作度の分散值を抑制できること から，末知外乱や外力の作用する作業に有効である。ただ し, 遊脚接地時に生ずる慣性力により, 安定余裕の最小值 が低下することに注意する必要がある。

上記の知見は，作業条件に応じた脚動作パラメー夕調整法の 設計指針となる，今後はこれらの性質を応用し，脚動作パラメー 夕調整によりアームの作業能力を増加させる制御手法の提案を 行う.

\section{参 考 文 献}

[1] 新井健生：“作業移動型ロボットの研究動向と今後の展開”，日本口 ボット学会誌, vol.13, no.7, pp.896-899, 1995.

[2] 日本ロボット学会編：作業移動型ロボット研究専門委員会報告書, 1996.

[3] Y.F. Zheng and A. Yin: "Coordinating multilimbed robots for generating large cartesian force," Proc. of IEEE Int. Conf. on Robotics and Automation, vol.3, pp.1653-1658, 1990.

[4] H. Adachi, N. Koyachi, K. Nishimura and T. Arai: "Control of a Manipulator Mounted on a Quadruped," Proc. IEEE/RSJ Int. Conf. Intelligent Robots and Systems, pp.883-888, 1996.

[5] Q. Huang, S. Sugano and K. Tanie: "Stability Compesation of a Mobile Manipulator by Manipulator Motion: Feasibility and Planning," Proc. IEEE/RSJ Int. Conf. Intelligent Robots and
Systems, pp.1285-1292, 1997.

[6] E.F. Fukushima, S. Hirose and T. Hayashi: "Basic Manipulation Considerations For The Articulated Body Mobile Robot," Proc. IEEE/RSJ Int. Conf. Intelligent Robots and Systems, pp.386-393, 1998.

[7] 福島, 広瀬: “最適力配分を考虑した計算卜ルク法に基づく節体幹型移 動ロボットの姿勢制御の提案”，日本ロボット学会誌，vol.18，no.4 pp. 576-583, 2000.

[ 8 ] 小谷内, 安達, 新井: “脚・腕統合リムメカニズム—腕転用脚機構の運動 学解析—”, 日本ロボット学会誌, vol.14, no.7, pp.968-976, 1996.

[9] 広瀬, 竹中, 五味, 小澤：“人間型ロボット”, 日本ロボット学会誌 vol.15, no.7, pp.983-985, 1997.

[10] K. Hirai, M. Hirose, Y. Haikawa and T. Takenaka: "The Development of Honda Humanoid Robot," Proc. of IEEE Int. Conf on Robotics and Automation, vol.2, pp.1321-1326, 1998.

[11] 人間協調・共存型ロボットシステム研究開発成果発表会報告書, (財) 製造科学技術センター, 1999.

[12] J. Yamaguchi, E. Soga, S. Inoue and A. Takanishi: "Development of a Bipedal Humanoid Robot: Control Method of While Body Cooperative Dynamic Biped Walking," Proc. of IEEE Int. Conf. on Robotics and Automation, pp.368-374, 1999.

[13] 玄, 青柳, S.A. Setiawan, 山口, 高西: “2 足歩行型ヒューマノイド ロボットと人間との物理的インタラクション一手を用いた人間追従歩 行—”, 第 16 回日本ロボット学会学術講演会予稿集, pp.951-952, 1998.

[14] 田宮, 稲葉, 井上：“人間型ロボットの片足立脚動作における全身を 用いた実時間動バランス補償”，日本ロボット学会誌，vol.17，no.2, pp.268-274, 1999.

[15] 井上, 石井, 大川：“腕で作業をしながら移動する人間型ロボットの 実時間制御—Sagittal Plane 内の運動の制御—”, 日本ロボット学会 誌, vol.18, no.1, pp.75-86, 2000 .

[16] K. Inoue, H. Yoshida, T. Arai and Y. Mae: "Mobile Manipulation of Humanoids: Real-Time Control Based on Manipulability and Stability," Proc. IEEE Int. Conf. on Robotics and Automation, pp.2217-2222, 2000.

[17] T. Yoshikawa: "Manipulability of robotic mechanism," Intern. J. of Robotics Research, vol.4, no.2, pp.3-9, Summer, 1985.



吉田晴行 (Haruyuki Yoshida)

1973 年 4 月 2 生. 1997 年立命館大学理工学部機 械工学科卒業. 1999 年同大学大学院理工学研究科 博士前期課程修了. 同年, 大阪大学大学院基礎工学 研究科博士後期課程に進学. 現在に至る. 作業移動 型ロボットの研究に従事. 計測自動制御学会の学生 会員.

(日本ロボット学会学生会員)

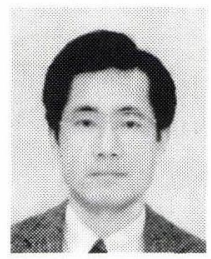

新井健生（Tatsuo Arai）

1952 年 1 月 6 日生. 1977 年東京大学大学院工学 系修士課程修了。工業技術院機械技術研究所を経 て, 現在大阪大学大学院基礎工学研究科教授. パラ レルメカニズム, マイクロマニピュレーション, 作 業移動型ロボット等の研究に従事. 工学博士. 1986 年 1987 年 MIT 客員研究員. 日本機械学会, 計 测自動制御学会, IEEE 等の会員. (日本ロボット学会正会員)

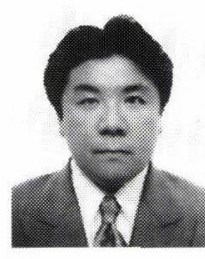

井上健司（Kenji Inoue）

1963 年 10 月 10 日生. 1988 年束京大学大学院工学 系研究科修士課程修了. 同年, 東京大学工学部助手. 1993 年大阪大学工学部助手. 1995 年同学部溝師. 1998 年より大阪大学大学院基礎工学研究科講師と なり現在に至る。超圥長マニピュレータ，ロボット協 調システム, 人間型ロボットの研究に従事. 工学博 士. 日本機械学会, 精密工学会等の会員. (日本ロボット学会正会員)

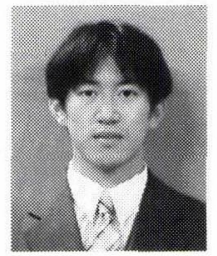

前 泰志 (Yasushi Mae)

1971 年 3 月 11 日生. 1993 年大阪大学工学部電子 制御機械工学科卒業, 1998 年同大学大学院工学研 究科電子制御機械工学専攻博士課程修了. 工学博 士. 同年, 同大学大学院基礎工学研究科助手. コン ピュータビジョン, 知能ロボットの研究に従事. 情 報処理学会の会員. (日本ロボット学会正会員) 